\title{
Environmental effects of the feral donkey Equus asinus (Linnaeus, 1758) in Al-Ula governorate, western Saudi Arabia
}

\author{
Walid Fathy Mohamed* \\ Dept. of Biological and Geological Sciences, Faculty of Education, Ain Shams \\ University, Roxy, Cairo, Egypt \\ Dept. of Biology, College of Sciences and Arts, \\ Taibah University, Al-Ula branch, Al Madinah Al Munawwarah, KSA \\ *Corresponding author: walidfathy72@yahoo.com
}

\begin{abstract}
Alien animals cause drastic and negative impacts on biota and ecosystems. The feral donkey Equus asinus is an invasive alien species in Saudi Arabia. Damage to farms and plants consumed by feral donkeys was studied between Al-Ula and Al-Wajh governorates to spot their harmful effects in this region and propose possible solutions to the problems they caused. Surveys and direct interviews, and conversations with farmers and villagers were the selected methods used to collect information. As a result, prevention and management actions were suggested to decrease the number of feral donkeys. In addition, a good investment potential was proposed to get some benefits from them.
\end{abstract}

Keywords: Alien species; Al-Ula; feral donkey; Saudi Arabia; wildlife damage.

\section{Introduction}

An animal species is considered alien invasive species if humans introduce it to any region or area where it did not previously live naturally; it becomes a pest in this new area causing severe threats to biodiversity or human activities (Choquenot,1990; Crowl et al., 2008).

During the Pleistocene era, the mammals of Family Equidae or the horse family were the most abundant animals at this time; their medium size characterized them, live in grasslands of Africa, Asia, and the two Americas (Epstein, 1971; Clutton-Brock, 1992; Huggins, 2002; Beja-Pereira et al., 2004; Huffman, 2004). Today only seven species of wild equids exist, and many of them are endangered (Ziccardi, 1970; Klingel, 1990; Kingdon, 1997; Wilson \& Reeder, 2005; Svendsen, 2008; Ransom \& Kaczensky, 2016). The domestic ass, or donkey, is also known as Equus asinus (Ziccardi, 1970; Wilson \& Reeder, 2005). Loudon (1825) stated that the ass 'is a native of the mountainous deserts of Tartary, Arabia, Persia, and other parts of the Asiatic continent; and at present is very generally domesticated throughout most civilized countries. Beja-Pereira et al., (2004) and Kugler et al. (2008) suggested that the donkey has evolved from the wild African species, and it was first domesticated in Libya; their surveys were carried out based on mitochondrial DNA (mtDNA) collected from many different specimens.

Over 95\% of the donkeys are used for work worldwide (Kimura et al., 2011). They are used in carrying loads because of their weight-bearing capacity, transportation tolerance for 
long-distance traveling, and farm plowing (Klingel, 1977; Pearson \& Ouassat, 1996; Rossel et al., 2008). In other countries, they are considered great assistants in threshing grains and raising water (Rossel et al., 2008). Donkeys are rarely owned or raised unless used for working (Wilson \& Reeder, 2005). Ancient Egyptians milked females due to higher content of sugars and proteins than those cows (McCort, 1980; Meadow \& Uerpmann, 1991). Estimation of the population of donkeys provides valuable indicators of donkey work worldwide. The number of domestic donkeys in civilized countries is minimal (Huggins, 2002).

Feral donkeys are considered invasive in some countries such as Australia and USA. This is because donkeys were brought to Australia to use them in transportation. Still, they escaped due to the lack of fences, so they officially declared that the donkeys became a pest after reaching about 5 million feral donkeys in 2005 (Clive, 2007). In the USA, donkeys were introduced as a species initially descended from the African wild ass and not native to North America. In a few years, they caused severe damage to the natural native plants and ecosystems, and they compete with native bighorn sheep and desert tortoises to obtain food (Litten et al., 2004).

The feral donkey E. asinus recorded from Saudi Arabia is closely shaped to the horse from the external features (Ransom \& Kaczensky, 2016) with a large head, long ears, and a tufted tail. It has a messy thin erect mane and a thin stripe on its back with little stripes on its legs and; a whitish belly (Burnham, 2002). Colors vary significantly from black, grey, brown, and white. The hair of feral donkeys can be short, straight, curly, or woolly. There is almost no sexual dimorphism in E. asinus, except for slight differences between males and females (Eley \& French, 1993; Huggins, 2002).

E. asinus has strong teeth adapted to graze plant materials. Its large flat-surfaced teeth can effectively tear grasses, shrubs, and desert plants. Feral donkeys feed mainly on grasses, representing about 30\% of their diet (Woodward, 1979; McCort, 1980; McDonnell, 1998; Huggins, 2002).

Domestic donkeys are widely distributed and can be found everywhere globally; they are also adapted for desert life (Svendsen, 2008). For example, feral donkeys in Saudi Arabia prefer warm, dry climates, so they are scattered in many sites characterized by low rainfall and sparse vegetation (personal observations).

Feral donkeys in Saudi Arabia usually live in small herds; each herd is composed of 1-2 males and 5-6 females. Herds determine their territories using sounds and fecal piles (personal observations). Feral donkeys have no common diseases, competitors, or predators, so groups grow quickly and continuously (Pimentel et al., 2001; Ransom \& Kaczensky, 2016).

Equus asinus has severe harmful effects on native flora and fauna. Damage to soils, water resources, crops, and wildlife have been documented in several locations due to the 
difficulty of managing and treating this species as invasive (Choquenot, 1990; Crowl et al., 2008). Several feral donkeys are growing and roaming free across desert regions of Saudi Arabia (Moehlman, 2002).

In 2004, the Department of the Environment and Heritage in Australia declared that the feral donkey E. asinus is considered an environmental pest; staff members recorded severe damage to vegetation and drinkable water by donkeys' hard hoofs that may cause low productivity of farms. In addition, donkeys are essential carriers of different endemic and exotic diseases (Woolnough et al., 2014).

During the last decade, Saudis used to raise donkeys. They captured feral donkeys to transform them into domesticated ones to use them on their farms to plough fields, carry loads, and carry water jars and clovers. However, throughout the last 30 years, feral donkeys have become a severe problem in Saudi Arabia due to using modern equipment in farming and vehicles for transportation and carrying needs. So, Saudis started to free the donkeys in open deserts away from their inhabited areas until the number of donkeys increased rapidly, causing severe environmental and agricultural problems (Wilson \& Reeder, 2005).

FAO Statistics Division (FAOSTAT) (faostat.fao.org) recorded about 55,000 ass in 1961 in Saudi Arabia, and the number reached 100,000 ass in 2013. In 2011, the Invasive Species Specialist Group (ISSG) stated that feral donkeys were introduced to Saudi Arabia and turned in a short time be invasive animals.

The present work sheds the spotlight on the adverse environmental effects of feral donkeys on humans, farms, and plants in Al-Ula governorate in the northern part of Al Madinah Al Munawwarah region in the Kingdom of Saudi Arabia through doing direct interviews with the farmers anddwellers along the road connecting between Al-Ula and AlWajh governorates in which a great deal of feral donkeys are abundant. This work aimed to study the harmful environmental effects caused by the feral donkeys in this area to suggest new potential solutions to solve the problems resulting from the high density of these donkeys.

\section{Materials and methods}

Twelve farms were visited regularly every two months along highway No. 8776, joining between Al-Ula and Al-Wajh governorates (Figure 1) from January 2018 to January 2020. Route No. 8776 extends for $225 \mathrm{~km}$. Each farm possessed only one adult donkey (total of 7 males and 5 females) aged 3-4 years. An intensive survey was prepared to collect information from farmers (2-3 male farmers on each farm) and 32 male dwellers through a fixed questionnaire. Information includes preferable plants eaten by the feral donkeys, ways of domestication, hazards that happened due to the existence of feral donkeys, and methods of prevention and control. External measurements, sexes, and weight of each live animal and three road-killed animals were taken accurately and recorded directly in separate sheet records. Wandering feral donkeys were recorded and photographed at eight sites along the 
road (Figure 2). It was observed that some of them were clustered in herds consisting of 5-7 donkeys. Samples of plants eaten by the feral donkeys were collected, photographed, dried, and identified to the species level according to El Akkad et al. (2017). Observations were carried out by driving a powerful car, and plants were collected from the study site on foot. The author was so careful during tracking and photographing feral donkeys in their natural hilly habitats and taking measurements because they defend themselves by strong kicks with their strong legs. Some donkeys may use biting as a defense mechanism besides their strong kicks (Kefena et al., 2011).

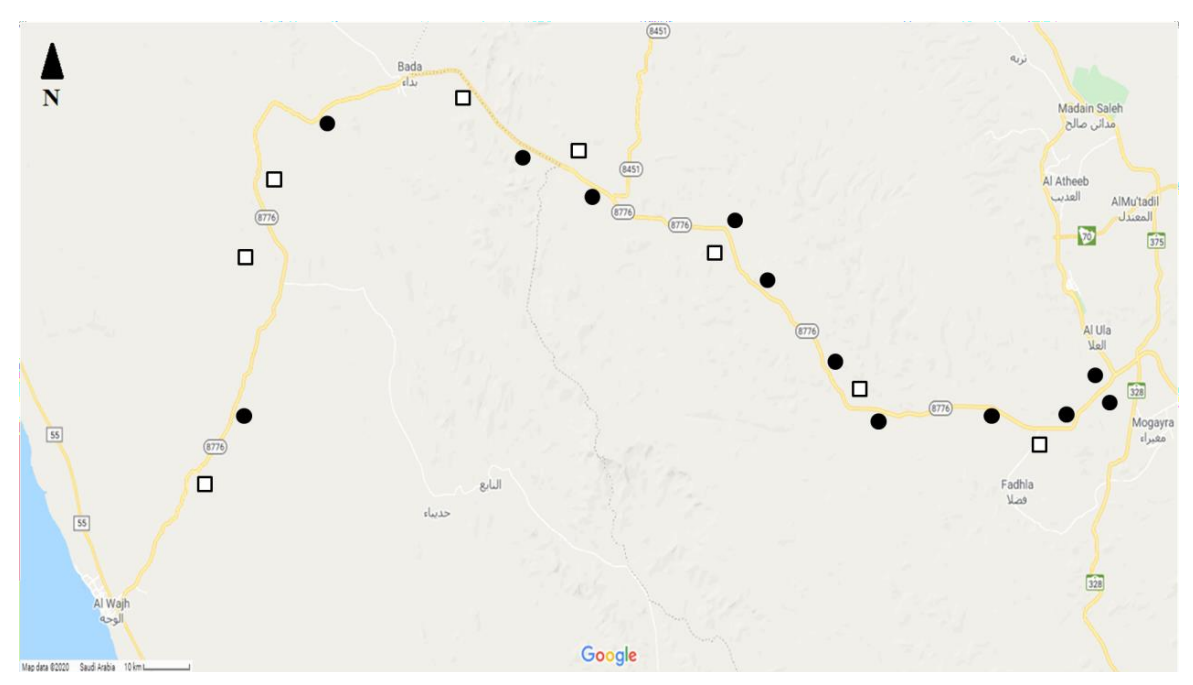

Fig. 1. Route No. 8776 joining between Al-Ula and Al-Wajh governorates (https://www.google.com.sa/maps/place/Saudi+Arabia/). Solid circles=farms; squares=photography sites.

\section{Results}

It was challenging to get near the feral donkeys roaming the hilly places and rocky hillocks for photography. However, $200 \mathrm{~m}$ was the nearest distance reached to the donkeys without running away (Figure 2). Natural plants found in the study area and eaten by the donkeys were collected and identified using references. The author identified seven wild plants species and their parts consumed by the donkeys in Table (1).

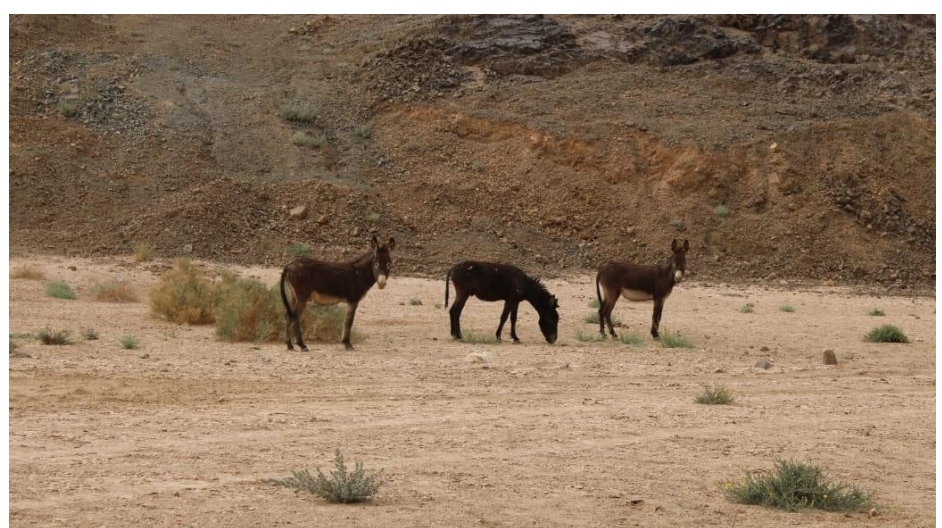

Fig. 2. Feral donkeys on route No. 8776 between Al-Ula and Al-Wajh governorates; $40 \mathrm{~km}$ away from Al-Ula governorate. 
Table 1. Plants and their parts are consumed by the feral donkey Equus asinus in the locations of the study sites.

\begin{tabular}{|l|l|l|}
\hline Plant & Family & Part eaten \\
\hline Citrullus colocynthis & Cucurbitaceae & Leaves, fruits, and flowers \\
\hline Senna Italica & Fabaceae & Leaves, fruits, and flowers \\
\hline Tribulus Terrestris & Zygophyllaceae & Leaves and flowers \\
\hline Aizoon sp. & Aizoaceae & Leaves and flowers \\
\hline Rumex vesicarius & Polygonaceae & Leaves \\
\hline Stipa capensis & Poaceae & Leaves \\
\hline Rhazya stricta & Apocynaceae & Leaves \\
\hline
\end{tabular}

The farmers capture the healthy young feral donkeys by ropes; then, they tie their four legs tightly on their farms to hinder them from escaping. Next, they connect them for about 24 weeks to transform them from feral animals to domesticated ones. During this time, farmers feed feral donkeys what sheep eat, such as grasses, hay, clover, and dried bread, to get used to eating the ordinary food of sheep.

Presently, donkeys are usually used on farms by the shepherds who ride them to follow cattle and sheep during herding. Means of measurement and weights of live donkeys from both sexes are listed in Table (2).

Farmers explained that feral donkeys cause severe damage to their farms, they cause direct threats on roads, they provoke dangerous accidents, and they may transmit diseases such as scabies to cattle and sheep. Table (3) summarizes the harmful effects caused by feral donkeys on route No. 8776 mentioned by the farmers and recorded personally during the present work. Figure (3) showed the frequency of damages reported from each farm based on the interview with the farmers.

Table 2. This study recorded the means and standard deviations (St. Dev.) of external measurements and weights of live males and females and road-killed males.

\begin{tabular}{|l|l|l|l|l|}
\hline Measurement & $\begin{array}{l}\text { Live males } \\
(\mathbf{n = 7})\end{array}$ & $\begin{array}{l}\text { Live females } \\
(\mathbf{n = 5})\end{array}$ & $\begin{array}{l}\text { Dead males } \\
(\mathbf{n = 3})\end{array}$ & St. Dev. \\
\hline Bodyweight & $320 \mathrm{~kg}$ & $290 \mathrm{~kg}$ & - & 176.73 \\
\hline Total body length & $210 \mathrm{~cm}$ & $200 \mathrm{~cm}$ & $215 \mathrm{~cm}$ & 7.64 \\
\hline Tail length & $51 \mathrm{~cm}$ & $47 \mathrm{~cm}$ & $49 \mathrm{~cm}$ & 2.00 \\
\hline Shoulder height & $130 \mathrm{~cm}$ & $120 \mathrm{~cm}$ & $128 \mathrm{~cm}$ & 5.29 \\
\hline Head length & $49 \mathrm{~cm}$ & $44 \mathrm{~cm}$ & $51 \mathrm{~cm}$ & 3.61 \\
\hline Neck length & $62 \mathrm{~cm}$ & $55 \mathrm{~cm}$ & $60 \mathrm{~cm}$ & 3.61 \\
\hline Hindfoot length & $135 \mathrm{~cm}$ & $121 \mathrm{~cm}$ & $134 \mathrm{~cm}$ & 7.81 \\
\hline Circumference & $182 \mathrm{~cm}$ & $151 \mathrm{~cm}$ & $184 \mathrm{~cm}$ & 18.50 \\
\hline Rear height & $156 \mathrm{~cm}$ & $145 \mathrm{~cm}$ & $157 \mathrm{~cm}$ & 6.66 \\
\hline
\end{tabular}


Table 3. Several harmful effects caused by feral donkeys w e r e recorded personally and recorded based on the interview with the 32 dwellers from the 12 farms along route No. 8776 between Al-Ula and Al- Wajh governorates during the time of the present study (PO) personal observation and (F) farm.

\begin{tabular}{|l|c|c|c|c|c|c|c|c|c|c|c|c|c|}
\hline Effect & PO & F 1 & F 2 & F 3 & F 4 & F 5 & F 6 & F 7 & F 8 & F 9 & F 10 & F 11 & F 12 \\
\hline Road accidents & 3 & - & - & - & - & - & - & - & - & - & - & - & - \\
\hline Damage fences & - & 2 & - & 2 & 1 & - & - & 1 & - & 2 & - & - & 1 \\
\hline Scatter hay & - & 1 & 1 & - & - & 1 & - & 1 & - & - & 1 & - & - \\
\hline $\begin{array}{l}\text { Consume } \\
\text { clover }\end{array}$ & - & 1 & 1 & 2 & - & - & 1 & 1 & 1 & 1 & 1 & - & 1 \\
\hline Gulp water & - & 2 & - & - & - & - & - & 1 & - & 2 & - & - & 1 \\
\hline $\begin{array}{l}\text { Breakwater } \\
\text { pipes }\end{array}$ & 5 & - & 1 & 1 & 1 & 1 & - & - & 1 & 1 & 1 & 1 & - \\
\hline $\begin{array}{l}\text { Destroy } \\
\text { agricultural } \\
\text { tools }\end{array}$ & 3 & 1 & - & 1 & 1 & 1 & - & 1 & 1 & 1 & - & 1 & - \\
\hline Smash crops & 7 & - & 1 & - & 1 & - & - & 1 & - & 1 & 1 & - & 1 \\
\hline $\begin{array}{l}\text { Uprooting } \\
\text { plants }\end{array}$ & 4 & - & - & 2 & 1 & 1 & 1 & - & - & 1 & - & - & - \\
\hline $\begin{array}{l}\text { Transmit } \\
\text { diseases }\end{array}$ & - & 1 & 1 & 1 & 1 & 1 & 1 & 1 & 1 & 1 & 1 & 1 & 1 \\
\hline
\end{tabular}

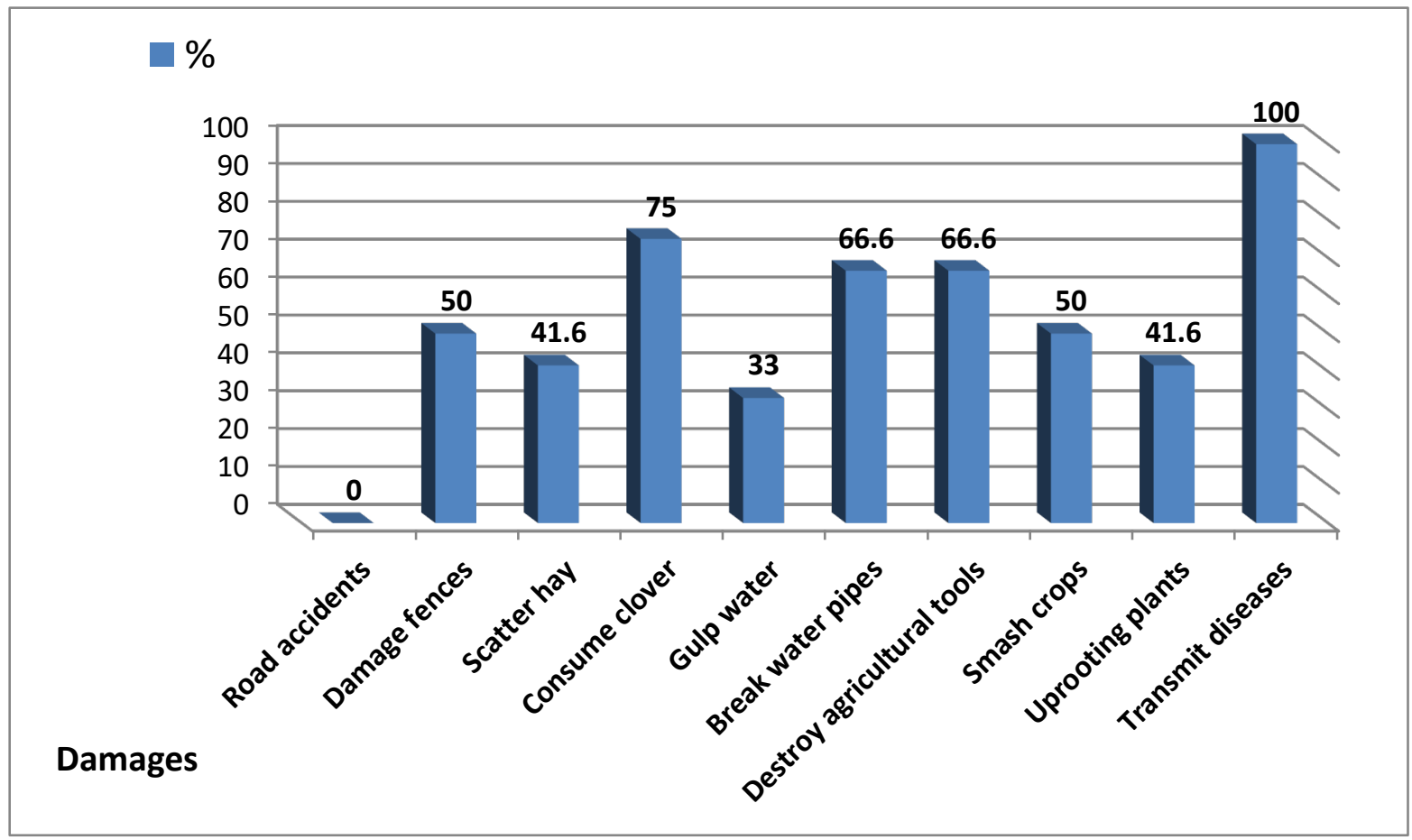

Fig. 3. The frequency (\%) of farms reported the type of damage that occurred by the feral donkeys based on the interview with farmers, excluding personal observations. 


\section{Discussion}

It was observed that feral donkeys in the study site are usually concentrated in areas with high vegetation cover and plenty of water supply; these findings are found near inhabitants' settlements and farms, so the feral donkeys typically come close to humans to obtain food and water (Reid et al., 1997).

Field observations showed feral donkeys grazed on many plant species (Table 1), especially Citrullus colocynthis. Seeds of C. colocynthis are edible but bitter; donkeys probably preferred to feed on them because of their high content of fats and proteins sufficient to give much energy to the animals; these observations match the findings of Schafferman et al. (1998). Farmers mentioned that feral donkeys feed on most natural plants grown in their habitats. No feral or domestic animal competes with them in their broad feeding spectrum; feral donkeys follow all types of plants whenever they grow to feed on them.

It was clear from the external measurements taken of the live animals that males are more significant than females (Table 2). This also reflects why males are heavier than females (mean $320 \mathrm{~kg}$ for males versus $290 \mathrm{~kg}$ for females). Farmers declared that males tend to eat more quantities of food than females, so they usually prefer to domesticate males because they have more robust bodies, live long, are fast-moving, and can withstand and perform heavy duties; these findings are agreed with de Aluja et al. (2005).

Due to urbanization, Saudis recently turned to using modern equipment in farming and gathering crops, so they became undependable in using donkeys on their farms and began to abandon them. They started to get rid of their domesticated donkeys by covering their eyes, transferring them far away from their territories, and releasing them to be sure that they would not return to their farms.

They release the animal in a vague spot because donkeys have a strong memory that enables them to return to any place they have been visited, even once from a long time ago.

Feral animals cause harm to wildlife in different ways (Fielding, 1991; Celermajer \& Wallach, 2019). Feral donkeys have no natural predators or population control in Saudi environments. It can breed and disperse quickly; occupying was areas. Saudi natural wildlife has no defenses against invaders and aliens and cannot compete with any species with no predators.

Released donkeys start to consume natural plants and drink water from wells and other sources in their new habitats. But donkeys working on farms and are released into the wild face severe problems because they used to eat clover and hay from farms, so they try to get the same foods from the nearest farms, especially after firing them from their work. Trying to get food and water from farms by these donkeys cause many problems and direct threats to farms and other domestic animals such as sheep and camels (Table 3).

Many destructive effects were recorded personally and confirmed by the owners of the farms caused by feral donkeys, which broke through the studied 12 farms. Breaking water pipes and smashing crops were the highest recorded problems caused by feral donkeys (13 times) due to their breaking into farms even through farm gates or destroying fences. Donkeys invade farms to get food and water, and so they trample crops and destroy pipes with their strong hooves. Villagers confirmed that some diseases such as mange a re 
transmitted directly from these feral donkeys to their grazing animals and camels; sharing conditions with domestic animals represents the second problem reported by dwellers and farmers in Saudi Arabia caused by feral donkeys (12 times). Also, donkeys may destroy agricultural tools with their hooves while searching for food and water (11 times). The most recorded stolen foods were clover and fresh planted plants (10 times), donkeys sometimes deliberate uprooting green planted plants to get food and plenty of water from these plants. Uprooting plants were recorded in the open areas personally, which may prevent regrowth, especially useful medicinal plants. Although road accidents are the most minor documented problems (3 times from personal observations) in Table (3), all villagers, farmers, and dwellers confirmed that it is the most annoying problem because feral donkeys have heavyweights and have robust bodies. They move foolishly on the roads and sometimes stand steady like a statue, and as a result, it causes lethal accidents for humans.

The problems mentioned above made the urgent need to prevent and control the feral donkeys in Al-Ula governorate, northwestern Saudi Arabia. Farmers avoid the invasion of donkeys to their farms by strengthening fences of farms to stop consuming clover and hay and stop the damage to agricultural tools, water pipes, trample of cultivated crops, and transmitting infected diseases to their domestic animals. (Stubbs 1999; Woolnough et al., 2014).

Stubbs (1999) suggested using the sterility technique as a non-lethal method, although it is currently limited in use up till now. This application can be used, but there is no certainty about its effectiveness in reducing the number of feral donkeys (Celermajer and Wallach, 2019). Control methods of feral donkeys suitable for Al-Ula governorate, northwestern Saudi Arabia, include capturing donkeys by trapping or roping them, placing them in reserves, and making fences along routes to prevent them from crossing crossroads; hence road accidents will be decreased gradually. This solution certainly should be authorized legally by the Saudi government.

Implanting a suitable policy focusing on raising farmers' awareness a b o u t not abandoning these animals in natural environments is considered one of the major solutions to this problem.

The author suggested an excellent solution to solve the problem of increasing feral donkeys in Saudi Arabia by trapping them in suitable reserves, feeding them proper food, then milking them and preparing their meat for exportation. Many countries drink donkeys' milk and eat donkeys' meat so that it will be a good investment for businesspeople and become a suitablesolution to solve this problem. Saudis do not drink donkeys' milk or eat donkeys' meat, so they can easily use the captured donkeys for milking and meat export to other countries. It will be an exciting venue for future economic feasibility analysis/research.

\section{Conclusion}

Feral donkeys are a severe problem in Saudi Arabia due to their potentially destructive effects on cultivated crops, road accidents, and transmitting diseases to domestic animals. It is worth finding solutions for these problems, especially with the increasing numbers of these animals. The present work focused on surveying the adverse effects of these feral donkeys along with route No. 8776 between Al-Ula and Al-Wajh governorates. Some possible solutions were 
suggested to prevent increasing feral donkeys and make a suitable investment to benefit from these animals.

\section{ACKNOWLEDGEMENTS}

Profound thanks to Atif Al Juhani, Abdullah Homoud, Walid Saad, and Marwan Awwad for their help during the present work. Great gratitude is also due to the owners of the farmers for allowing taking external measurements and weights of their donkeys to be used in the present study.

\section{References}

Beja-Pereira, A., England, P.R., Ferrand, N., Jordan, S., Bakhiet, A.O., et al. (2004). African origins of the domestic donkey. Science, 304 (5678): 1781.

Burnham, S.L. (2002). Anatomical differences of the donkey and mule. Proceedings of the American Association of Equine Practitioners, 48: 102-109.

Celermajer, D. \& Wallach, A. (2019). The Fate of the Illegible Animal: The Case of the Australian Wild Donkey. Animal Studies Journal, 8 (2): 229-258.

Choquenot, D. (1990). Rate of increase for populations of feral donkeys in Northern Australia. Journal of Mammalogy, 71: 151-155.

Clive, R. (2007). Domestication. Westport, Conn.: Greenwood Press. Pp. 179.

Clutton-Brock, J. (1992). Horse Power: A History of the Horse and the Donkey in Human Societies. Harvard University Press, Cambridge, USA. Pp. 192.

Crowl, T.A., Crist, T.O., Parmenter, R.R., Belovsky, G. \& Lugo, A.E. (2008). The spread of invasive species and infectious disease as drivers of ecosystem change. Frontiers in Ecology and the Environment, 6 (5): 238-246.

de Aluja, A.S., Tapia Perez, G., Lopez, F. \& Pearson, R.A. (2005). Live weight estimation of donkeys in central Mexico from measurements of thoracic circumference. Tropical Animal Health and Production, 37 (Suppl. 1): 159-171.

Department of the Environment and Heritage (2004). Feral horse (Equus caballus) and feral donkey (Equus asinus). Invasive Species, 1-4.

El Akkad, S., Souayah, N. \& Zalat, S. (2017). The Common Wild Plants in Al Ula Governorate (In Arabic). Taibah University Press, Pp. 204.

Eley, J.L. \& French, J.M. (1993). Estimating the bodyweight of donkeys. The Veterinary Record, 132: 249-251. 
Epstein H. (1971). The Origin of the Domestic Animals of Africa. African Publishing Corporation (APC), New York, NY, USA. Pp. 573. (Verified)

Food and Agricultural Organization of the United Nations (FAO). FAO Statistics Division (FAOSTAT), (faostat.fao.org). (Verified)

Fielding, D. (1991). The number and distribution of equines in the world. In Fielding D and Pearson RA (eds), Donkeys, mules and horses in tropical agricultural development. Proceedings of a colloquium held 3-6 September 1990, Edinburgh, UK. Centre for Tropical Veterinary Medicine, University of Edinburgh, UK. Pp 62-66.

Huffman, B. (2004). Equus asinus, African wild ass. An Ultimate Ungulate Fact Sheet. Pp. 2.

Huggins, B. (2002). Equus asinus. Animal Diversity Web.

Invasive Species Specialist Group (ISSG) (2011). A Compilation of Information Sources for Conservation Managers Involved in the Prevention, Eradication, Management and Control of the Spread of Invasive Alien Species that are a Threat to Native biodiversity and Natural Ecosystems.

Kefena, E., Beja-Pereira, A., Han, J.L., Haile, A., Mohammed, Y.K., et al. (2011). Ecogeographical structuring and morphological diversities in Ethiopian donkey populations. Livestock Science, 141: 232-241.

Kimura, B., Marshall, F.B., Chen, S., Rosenbom, S., Moehlman, P.D., et al. (2011). Ancient DNA from Nubian and Somali wild ass provides insights into donkey ancestry and domestication. Proceedings of the Royal Society (B) Biological Sciences, 278 (1702): 50-57.

Kingdon, J. (1997). The Kingdon field guide to African Mammals ( $2^{\text {nd }}$ ed). Princeton University Press. Pp. 544.

Klingel, H. (1977). Observations on social organization and behavior of African and Asiatic wild asses (Equus Africanus and E. hemionus). Zeitschrift fur Tierpsychologie, 44: 323- 331.

Klingel, H. (1990). Horses. In Grzimek's Encyclopedia of Mammals. Edited by S. P. Parker. New York: McGraw-Hill. Volume 4, Pp. 557-594.

Kugler, W., Grunenfelder, H.P. \& Broxham, E. (2008). Donkey breeds in Europe: Inventory, description, need for action, conservation. Monitoring Institute for Rare Breeds and Seeds in Europe in collaboration with SAVE Foundation, St Gallen, Switzerland. Pp. 124.

Litten, K.E., Mellor, D.J., Warburton, B. \& Eason, C.T. (2004). Animal welfare and ethical issues relevant to the humane control of vertebrate pests. New Zealand Veterinary Journal. 52: 1-10. 
Loudon, J.C. (1825). An Encyclopedia of Agriculture. Longmans, Green. Pp. 1375.

McCort, W.D. (1980). The behavior and social organization of feral asses (Equus asinus) on Ossabaw Island, Georgia. Ph.D. Thesis. The Pennsylvania State University. Pp. 438.

McDonnell, S.M. (1998). Reproductive behavior of donkeys (Equus asinus). Applied AnimalBehavior Science, 60: 277-282.

Meadow, R.H. \& Uerpmann, H.P. (1991). Equids in the Ancient World. Ludwig Reichert Verlag, Wiesbaden. Pp. 420.

MoehIman, P.D. (2002). Equids: Zebras, Asses, and Horses. Status Survey and Conservation Action Plan. IUCN/ SSC Equid Specialist Group. IUCN, Gland, Switzerland and Cambridge, UK. Pp. 190.

Pimentel, D., McNair, S., Janecka, J., Wightman, J., Simmonds, C., et al. (2001). Economic and environmental threats of alien plant, animal, and microbe invasions. Agriculture, Ecosystems and Environment, 84: 1-20.

Pearson, R.A. \& Ouassat, M. (1996). Estimation of the live weight and body condition of working donkeys in Morocco. The Veterinary Record, 138: 229-233.

Ransom, J.I. \& Kaczensky, P. (2016). Wild Equids: Ecology, Management, and Conservation. John Hopkins University Press. Pp. 248.

Reid, S.W.J., Godley, B.J., Henderson, S.M., Lawrie, G.J., Lloyd, D., et al. (1997). Ecology and behavior of the feral donkey, Equus asinus, population of the Karpas peninsula, northern Cyprus. Zoology in the Middle East, 14 (1): 27-36.

Rossel, S., Marshall, F., Peters, J., Pilgram, T., Adams, M.D., et al. (2008). Domestication of the donkey: timing, processes, and indicators. Proceedings of the Natural Academy of Sciences of the United States of America, 105 (10): 3715-3720.

Schafferman, D., Beharav, A., Shabelsky, E. \& Yaniv, Z. (1998). Evaluation of Citrullus colocynthis, a desert plant native in Israel, as a potential source of edible oil. Journal of Arid Environments, 40 (4): 431-439.

Stubbs, C.J. (1999). Feral burro Removal: New Solutions to an Old Problem (GPRA). Natural Resource Year in Review: publication D-1346.

Svendsen, E.D. (2008). The Professional Handbook of the Donkey ( $4^{\text {th }}$ ed.). Whittet Books Ltd. Pp. 448.

Wilson, D.E. \& Reeder, D.M. (2005). Mammal Species of the World ( $3^{\text {rd }}$ ed.). The Johns Hopkins University Press. Pp. 2000. 
Woodward, S.L. (1979). The social system of feral asses (Equus asinus). Zeitschrift fur Tierpsychologie, 49: 304-316.

Woolnough, A., Campbell, S., Rose, K. \& Hampton, J. (2014). Standard Operating Procedure (DON003): Capture of feral donkeys. Department of Agriculture and Food, Western Australia, 1-6.

Ziccardi, F. (1970). The African wild ass. Part I. African Wildlife, 24 (3-4). Pp. 202, 208, 287,292. (Verified)

Submitted: $\quad 03 / 09 / 2020$

Revised: $\quad 01 / 08 / 2021$

Accepted: $\quad 21 / 08 / 2021$

DOI: $\quad 10.48129 / \mathrm{kjs} .10506$ 